\title{
A Three-Year Single Center Quality of Life Study Among Adult Patients With Tuberculosis Arthritis who Underwent Surgery
}

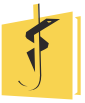 \\ Martin Lovie S. Bangcoy, MD, \\ Charles Abraham C. Villamin, MD
}

\begin{abstract}
Background: Tuberculosis arthritis is a type of extrapulmonary manifestation of tuberculosis (TB) and can be seen in many clinical forms, especially in developing countries.
\end{abstract}

Aims: This study will look into the quality of life (QoL) of patients who were diagnosed with tuberculous arthropathy of the extremity and underwent surgery at the University of Santo Tomas Hospital (USTH) from January 2014 to December 2016 using the Tagalog SF - 36 questionnaire.

Methods: All patients who underwent surgery for TB arthropathy at USTH for three years were included. The Tagalog SF - 36 questionnaire was administered to the patients during follow-up to assess the QoL scores. A detailed evaluation of the questions was performed to depict any pattern on specific areas that affect the QoL of patients.

Results: Patients who underwent surgery scored high for role emotional (mean 93.33) and lowest on the bodily pain scale (mean 69.2). Higher physical component scores (PCS) were noted in patients who underwent surgery in 2014 compared to 2015 and 2016. Higher mental component scores (MCS)

Martin Louie S. Bangcoy

martinloviebangcoy@gmail.com

Department of Orthopedics, University of Santo Tomas Hospital scores were also noted in patients operated in 2014 compared to 2015 and 2016. All patients have good QoL scores after surgery and complete medical treatment as demonstrated by the SF-36 scores. Tuberculous arthropathy can affect the physical and mental aspects of patients. No significant difference in mean scores by year were seen in all the scales of the SF-36 ( $p=>0.05)$.

Conclusion: All patients have good QoL scores after surgery and complete medical treatment as demonstrated by the SF-36 scores. QoL scores showed more improvement as the duration post-treatment is longer.

Keywords: Tuberculosis, TB arthritis, TB arthropathy, musculoskeletal tuberculosis, quality of life (QoL), SF-36

\section{INTRODUCTION}

Tuberculosis is known to be transmitted primarily through droplet inhalation or ingestion of Mycobacterium tuberculosis. The initial exposure can lead to infection that can be cleared by the host leading to a primary infection. This infection, however, can be reactivated from a latent infection. Hence, lymphogenous, hematogenous, or contiguous spread to other tissues and organ systems can occur. This is a disease that affects more commonly 
in developing countries and rare in developed countries. According to the World Health Organization 2014 global report on tuberculosis: It remains one of the world's deadliest communicable diseases. In 2013, 9 million people were reported to have acquired TB and 1.5 million died of the disease, of which 360,000 were HIV-positive. On a positive note, cases of TB are declining each year. It is reported that 37 million lives were saved between the years 2000 and 2013 through prompt diagnosis and treatment.[1]

Pulmonary involvement is the common site of TB but this deadly disease can infect any organ system of the body. Extrapulmonary TB is reported in 14\% of patients, with bony involvement in $1 \%-8 \%$ of the time. Concurrent pulmonary and osseous involvement happens in $50 \%$ of patients. The most commonly affected bone is the vertebra in $30 \%-50 \%$ of patients. The usual osseous involvements are on the major weight-bearing joints of the lower extremity like the hip and knee, followed by the foot, elbow and hand. The common sites involved in musculoskeletal TB include the spine $(50 \%)$, pelvis $(12 \%)$, hip and femur $(10 \%)$, knee and tibia $(10 \%)$, ribs $(7 \%)$, ankle/shoulder $(2 \%)$, elbow or wrist $(2 \%)$ and multiple sites (3\%).[2]

Tuberculous synovitis or arthritis of the knee has a characteristic monoarticular involvement and commonly affects the weight-bearing joints such as the knee and hip. The disease initially presents as syn-

Table 1. Summary of USTH patient profiles having TB arthropathy

\begin{tabular}{|c|c|c|c|c|c|c|}
\hline Patient & Age & Sex & Diagnosis & $\begin{array}{l}\text { Extremity/ } \\
\text { Part involved }\end{array}$ & $\begin{array}{l}\text { Procedure } \\
\text { done }\end{array}$ & Follow-up \\
\hline 1 & 72 & $\mathrm{~F}$ & TB arthritis & Knee - L & $\begin{array}{l}\text { Arthrotomy and } \\
\text { synovectomy }\end{array}$ & 12 \\
\hline 2 & 44 & $\mathrm{~F}$ & TB arthritis & Shoulder - L & $\begin{array}{c}\text { Arthrotomy and } \\
\text { debridement }\end{array}$ & 16 \\
\hline 3 & 53 & $\mathrm{~F}$ & TB arthritis & Knee - R & $\begin{array}{l}\text { Debridement, } \\
\text { arthrotomy and } \\
\text { synovectomy }\end{array}$ & 24 \\
\hline 4 & 33 & M & TB arthritis & Ankle - L & $\begin{array}{l}\text { Arthrotomy and } \\
\text { debridement }\end{array}$ & 12 \\
\hline 5 & 41 & M & TB arthritis & Knee - R & $\begin{array}{c}\text { Arthrotomy and } \\
\text { debridement }\end{array}$ & 26 \\
\hline 6 & 56 & M & TB arthritis & Wrist - R & $\begin{array}{c}\text { Arthrotomy and } \\
\text { debridement }\end{array}$ & 10 \\
\hline 7 & 22 & M & TB arthritis & Knee - R & $\begin{array}{l}\text { Arthrotomy, } \\
\text { synovectomy, } \\
\text { excision of mul- } \\
\text { tiple soft tissue } \\
\text { masses }\end{array}$ & 16 \\
\hline 8 & 60 & M & TB arthritis & Elbow - R & $\begin{array}{c}\text { Arthrotomy and } \\
\text { debridement }\end{array}$ & 12 \\
\hline 9 & 44 & $M$ & TB arthritis & Knee - R & $\begin{array}{c}\text { Arthrotomy and } \\
\text { debridement }\end{array}$ & 6 \\
\hline 10 & 30 & $\mathrm{~F}$ & TB tenosynovitis & Hand - R & $\begin{array}{l}\text { Debride- } \\
\text { ment and } \\
\text { synovectomy }\end{array}$ & 12 \\
\hline 11 & 60 & $M$ & TB synovitis & Wrist - L & $\begin{array}{c}\text { Arthrotomy and } \\
\text { debridement }\end{array}$ & 9 \\
\hline 12 & 71 & $\mathrm{~F}$ & TB synovitis & $\begin{array}{c}\text { Elbow - R; } \\
\text { knee, wrist - L }\end{array}$ & $\begin{array}{c}\text { Arthrotomy and } \\
\text { debridement }\end{array}$ & 9 \\
\hline 13 & 48 & $\mathrm{~F}$ & TB synovitis & Ankle - L & $\begin{array}{c}\text { Arthrotomy and } \\
\text { debridement }\end{array}$ & 6 \\
\hline 14 & 46 & M & TB arthritis & Knee - L & $\begin{array}{c}\text { Arthrotomy and } \\
\text { debridement }\end{array}$ & 8 \\
\hline 15 & 42 & $\mathrm{~F}$ & TB tenosynovitis & Hand - R & $\begin{array}{l}\text { Debridement and } \\
\text { synovectomy }\end{array}$ & 12 \\
\hline
\end{tabular}


ovitis leading to arthritis with demineralization, erosions and lastly joint destruction.[3] Early changes are seen through MRI. Joint effusion will show hyperintense signal on T2W, but debris, loose bodies and hemosiderin deposits can be seen as hypointense signals on both T1W and T2W.

The primary goals in the treatment of bone TB are eradicating the infection, limiting the deformity, maintaining joint mobility, reducing pain and discomfort. Most of the patients can be treated conservatively with chemotherapy, rest, and gradual remobilization. On the other hand, operative management includes arthrotomy, synovectomy, and curettage with bone grafting of the articular defect; curettage and bone grafting of extra-articular lesions; joint and bone resection; abscess drainage; arthrodesis; and amputation.[7]

The objective of this study was to determine the QoL of adult patients with TB arthropathy who underwent surgery at the USTH from January 2014 to December 2016. Furthermore, the secondary objectives were to assess the PCS score and MCS score of TB arthritis adult patients and present the following scales using the Tagalog SF-36 v2: a) Physical functioning; b) Role limitations due to physical health; c) Role limitations due to emotional problems; d) Energy/fatigue; e) Emotional well-being; f) Social functioning; g) Pain; h) General health. Moreover, the clinical profile and outcome of surgically treated adult patients with TB arthritis were looked into.

This is a descriptive cross-sectional study conducted over a period of 3 years among admitted adult patients in the USTH diagnosed and treated as TB arthritis. The study included all adult patients with TB arthritis who underwent surgery at the USTH from January 2014 to December 2016. The patients were identified throughout patient and in-patient records of the Department of Orthopedics from January 2014 to December 2016. Also, the diagnosis of TB arthritis was conferred with the final histopathology report and was reviewed at the records section of the pathology laboratory.

Once identified, the charts, records and imaging data were reviewed. Inclusion criteria for this study were adult Filipinos (>18 years old) who had been histologically diagnosed with TB arthritis in any part of the extremity, patients treated medically with anti-TB medications for at least 9 months, patients who were surgically managed at the USTH with at least 6 months follow-up after completion of treatment.
Patients were excluded from this study if no consent was given by the patient, if they were unable to answer the Tagalog SF - 36 v2 questionnaire and also patients with other bone and soft tissue conditions that may affect the function of the extremity (such as other arthropathies).

The scores of the 8 scales of the SF-36 (set to a metric of 0-100) including two norm-based summary scores (PCS and MCS) were computed. Independent t-test and one-way Analysis of variance (ANOVA) were used to compare the mean SF-36 scores by extremity affected and year of surgery, respectively. Significant ANOVA results were further analyzed. A p-value $\leq 0.05$ was considered statistically significant.

\section{RESULTS}

A total of 15 TB arthritis patients underwent surgery in the USTH between January 2014 and December 2016-5 patients for each year. A slightly higher proportion of TB arthritis patients were male (Table 2). About half $(6)$ of the patients had diabetes mellitus (DM), $27 \%$ (4) have a family history of TB and $13 \%$ (2) have a history of TB treatment (Figure 1). More than half of the patients (8) were affected in their lower extremities. One (1) patient was diagnosed with TB arthritis in both the upper and lower extremities (Figure 2). The majority (40\%) were affected in the knee/tibia area (6), followed by the ankle, hand and wrist with two (2) pathologies, respectively. Other pathologies (1) include the shoulder and elbow. Only 1 patient had multiple sites-the knee, wrist and elbow (Figure 3). A majority of the patients had stage 2 (late) TB arthritis. Only 2 patients were diagnosed with stage 1 (early) (Figure 4). All

Table 2. Demographic profile of $T B$ arthritis patients in USTH $(n=15)$

\begin{tabular}{ll}
\hline CHARACTERISTICS & $\mathbf{N} \%$ \\
\hline $\begin{array}{l}\text { Age at the time of } \\
\text { surgery } \\
<40 \text { years old }\end{array}$ \\
$40-59$ years old & $3(20)$ \\
$\geq 60$ years old & $8(53)$ \\
Sex & $4(27)$ \\
Male & \\
Female & $8(53)$ \\
\hline
\end{tabular}




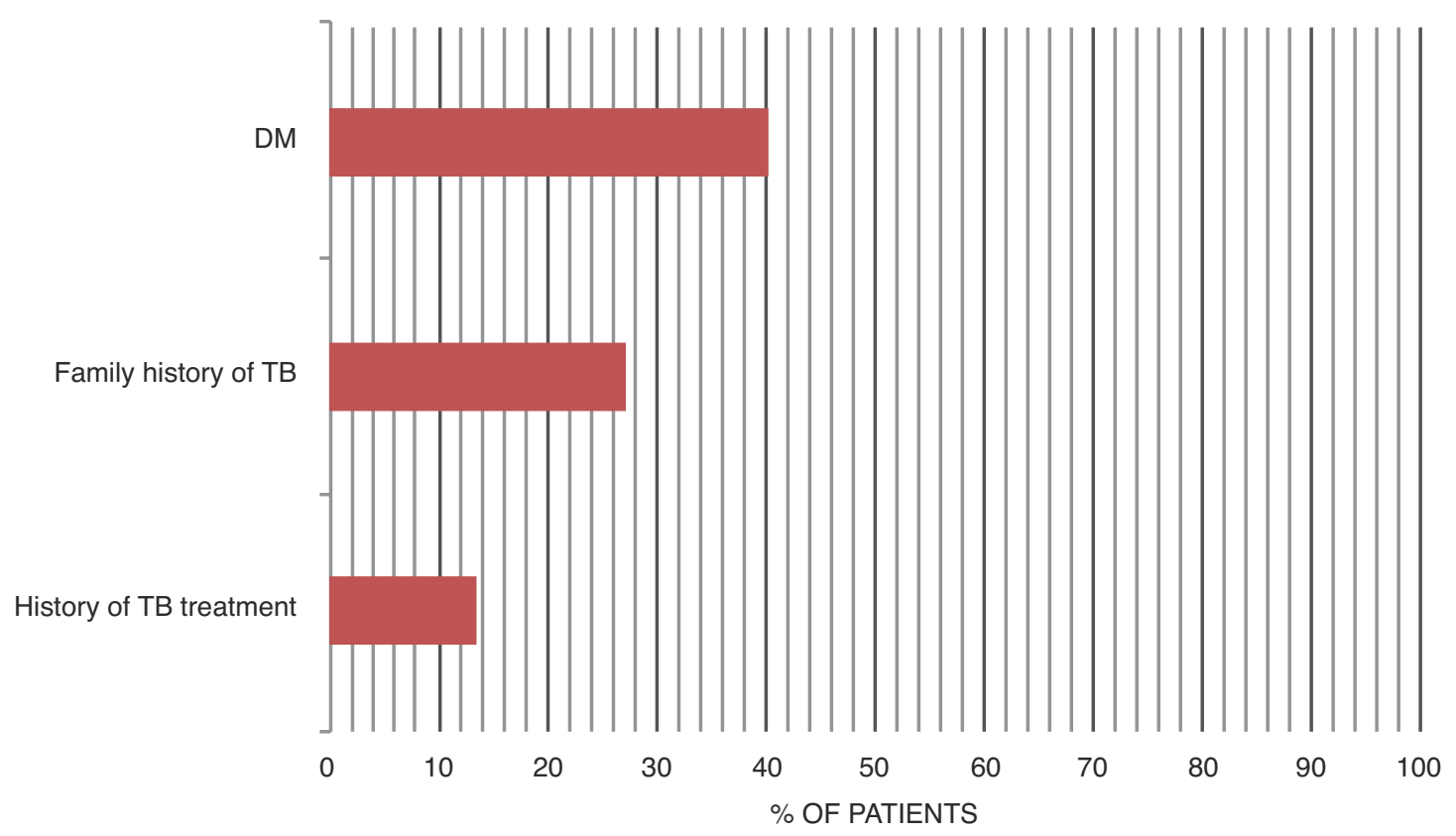

Figure 1. Clinical profile of TB arthritis patients in USTH $(n=15)$

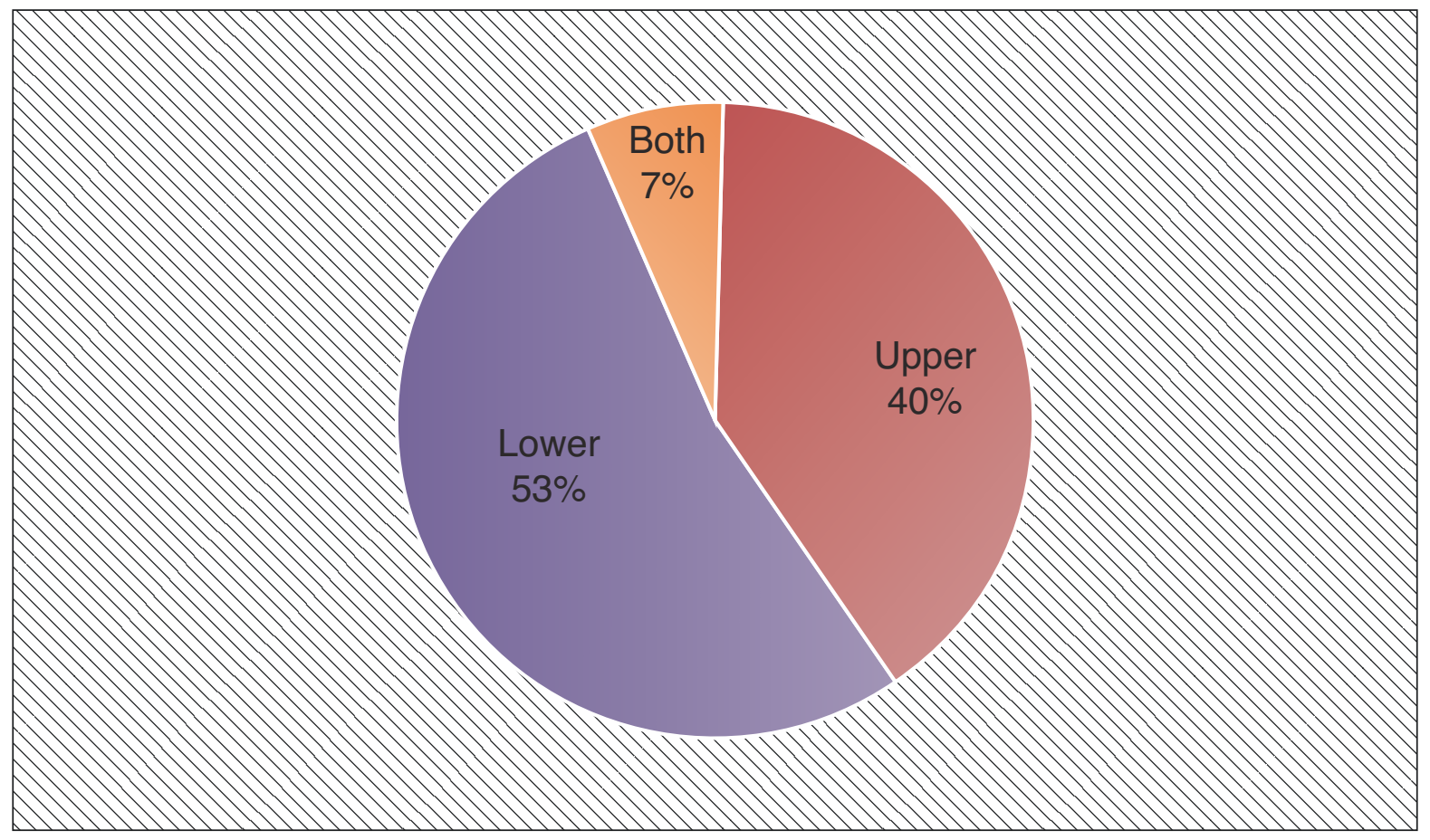

Figure 2. Extremity affected by TB arthritis in USTH $(n=15)$

patients underwent some form of debridement with or without arthrotomy or synovectomy.

The QoL scores were measured using the Taga$\log$ SF-36 v2. Table 3 summarizes the mean SF-36 scores of patients by year of surgery. Based on the overall score of TB arthritis patients who underwent surgery, QoL is considered to be relatively high, especially for role emotional (mean: 93.33). The lowest mean score was obtained for the bodily pain scale (mean: 69.2). The mean score in bodily pain is significantly higher in patients who underwent surgery in 2014 compared to 2016 . The mean score in mental health is significantly higher in patients who underwent surgery in 2014 compared to 2016 . No significant difference in mean scores by year was noted in the following scales: general health $(G H)$, physical function (PF), role physical (RP), vitality (VT), social function (SF) and role emotional (RE). It can 


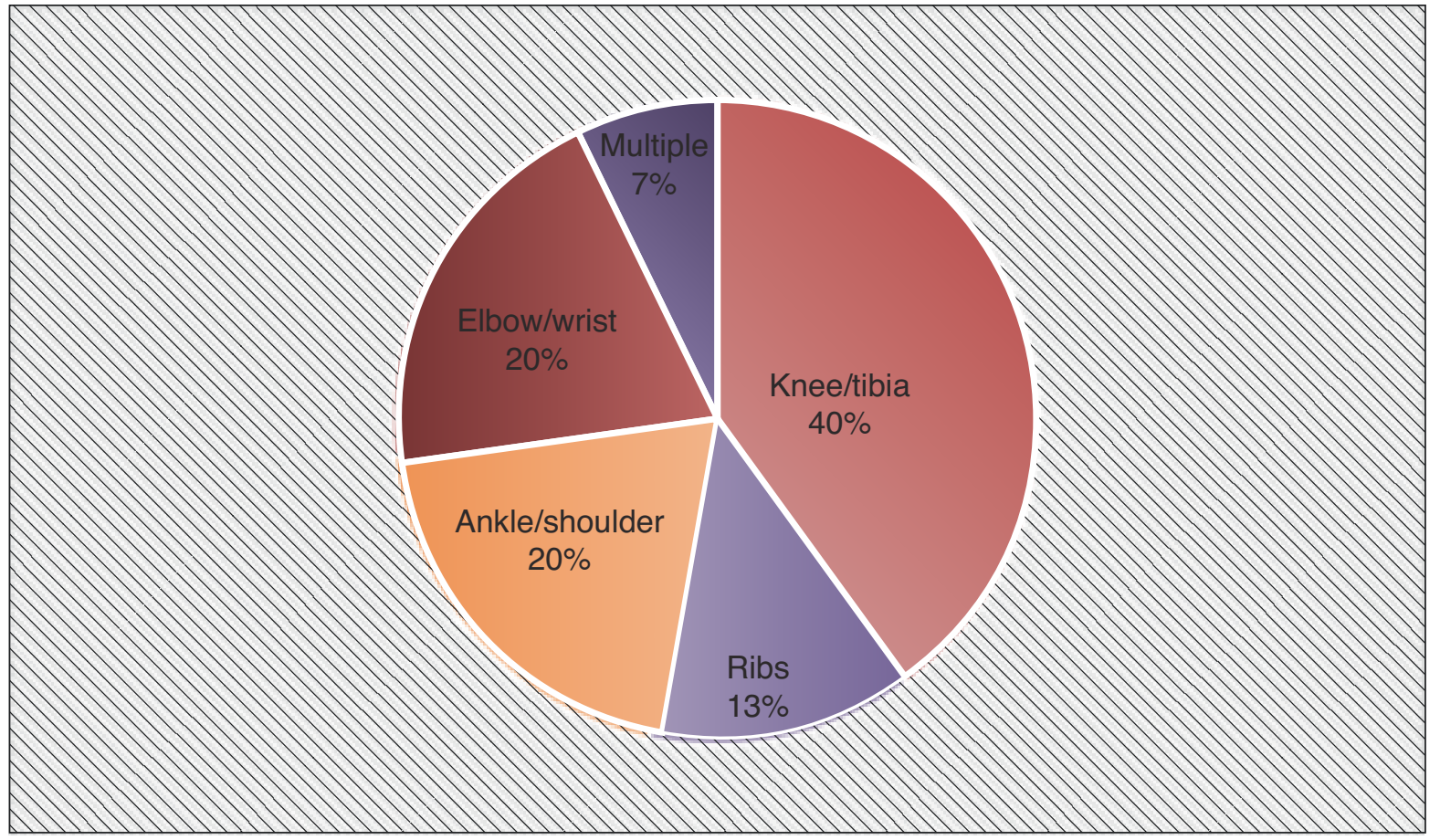

Figure 3. Specific site of TB arthritis of patients seen in USTH $(n=15)$

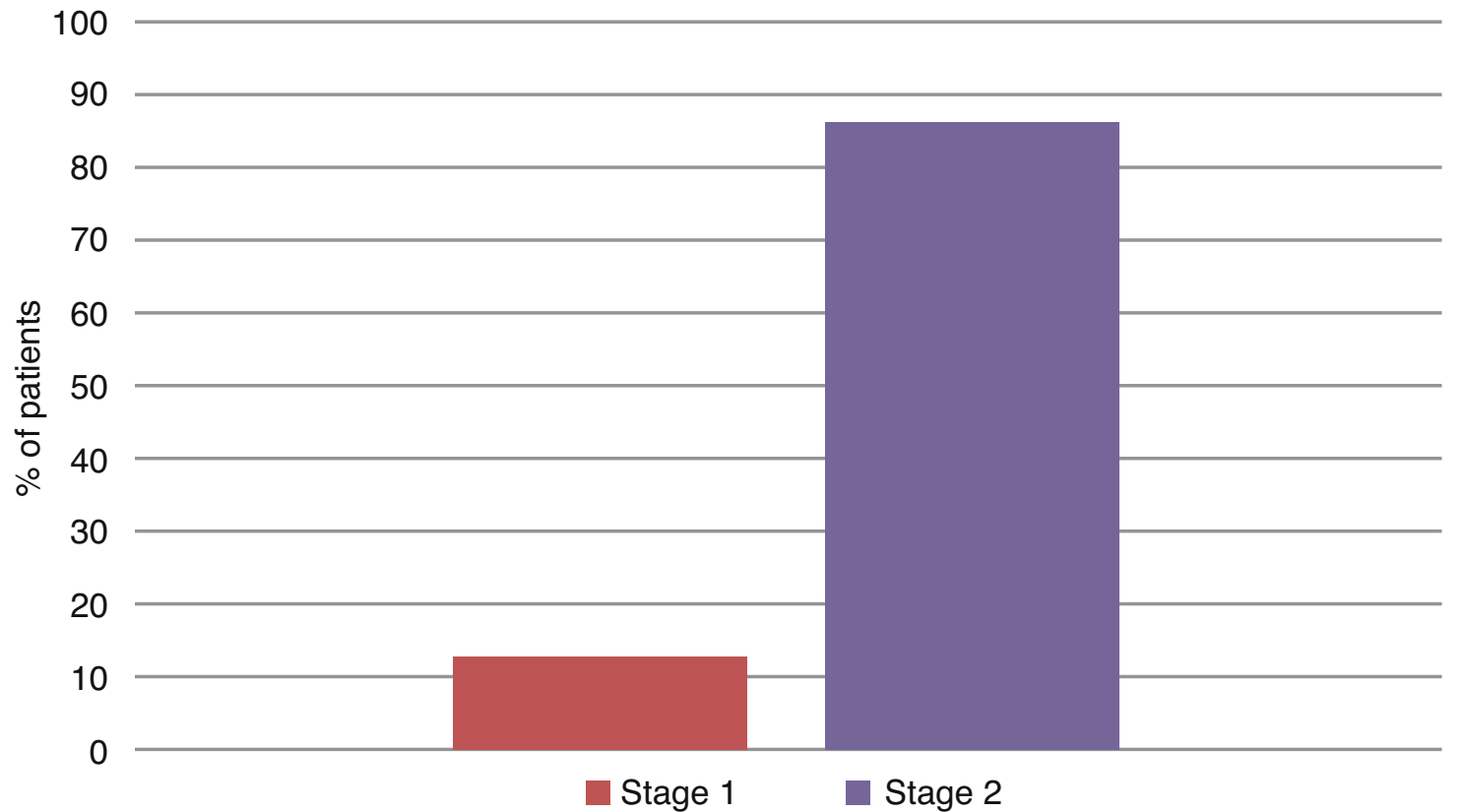

Figure 4. Stage of TB arthritis of patients seen in USTH $(n=15)$

be observed that the highest mean score is exhibited by patients who underwent surgery in 2014 and the lowest in patients who underwent surgery in 2016. The mean PCS and MCS score by year of surgery $(n=15)$ are summarized in Figure 5. There is no significant difference in mean PCS and MCS scores by year of surgery $(p=0.1837$ and $p=0.1557$, respectively). There are lower mean scores in patients who underwent surgery in 2016 and higher mean PCS scores in patients who underwent surgery in 2014 compared to patients who underwent surgery in 2015 and 2016. There is a higher mean MCS score in patients who underwent surgery in 2014 compared to 2015 and 2016. The mean SF-36 scores by year of extremity affected $\left(n=14^{*}\right)$ are depicted in Figure 6. One patient with multiple extremity pathology was excluded. No statistical significance was detected in mean SF-36 scores by the extremity affect- 
Table 3. Mean SF-36 scores of patients in USTH with TB arthropathy by year of surgery

\begin{tabular}{lccccc}
\hline & TOTAL & $\begin{array}{c}\mathbf{2 0 1 4} \\
(\mathbf{n = 5})\end{array}$ & $\begin{array}{c}\mathbf{2 0 1 5} \\
(\mathbf{n = 5})\end{array}$ & $\begin{array}{c}\mathbf{2 0 1 6} \\
(\mathbf{n = 5})\end{array}$ & P VALUE \\
\hline General health (GH) & $79.40 \pm 19.20$ & $87.2 \pm 17.05$ & $80.8 \pm 8.44$ & $70.2 \pm 27.28$ & 0.3967 \\
Physical function (PF) & $79.67 \pm 17.00$ & $90 \pm 10.61$ & $76 \pm 13.87$ & $73 \pm 22.25$ & 0.2532 \\
Role physical (RP) & $83.33 \pm 31.15$ & $100 \pm 0$ & $100 \pm 0$ & $65 \pm 48.73$ & 0.1170 \\
Bodily pain (BP) & $69.2 \pm 6.57$ & $69.2 \pm 6.57$ & $84.8 \pm 20.81$ & $53.6 \pm 11.50$ & $0.0156^{*}$ \\
Vitality (VT) & $72.50 \pm 13.53$ & $77.5 \pm 9.48$ & $77.5 \pm 13.69$ & $62.5 \pm 13.26$ & 0.1252 \\
Social function (SF) & $85.83 \pm 17.59$ & $92.5 \pm 11.18$ & $90 \pm 10.46$ & $75 \pm 25$ & 0.2492 \\
Role emotional (RE) & $93.33 \pm 25.82$ & $100 \pm 0$ & $100 \pm 0$ & $80 \pm 44.72$ & 0.3966 \\
Mental health (MH) & $77.67 \pm 8.84$ & $77 \pm 5.70$ & $85 \pm 9.35$ & $71 \pm 5.48$ & $0.0273^{*}$ \\
\hline
\end{tabular}

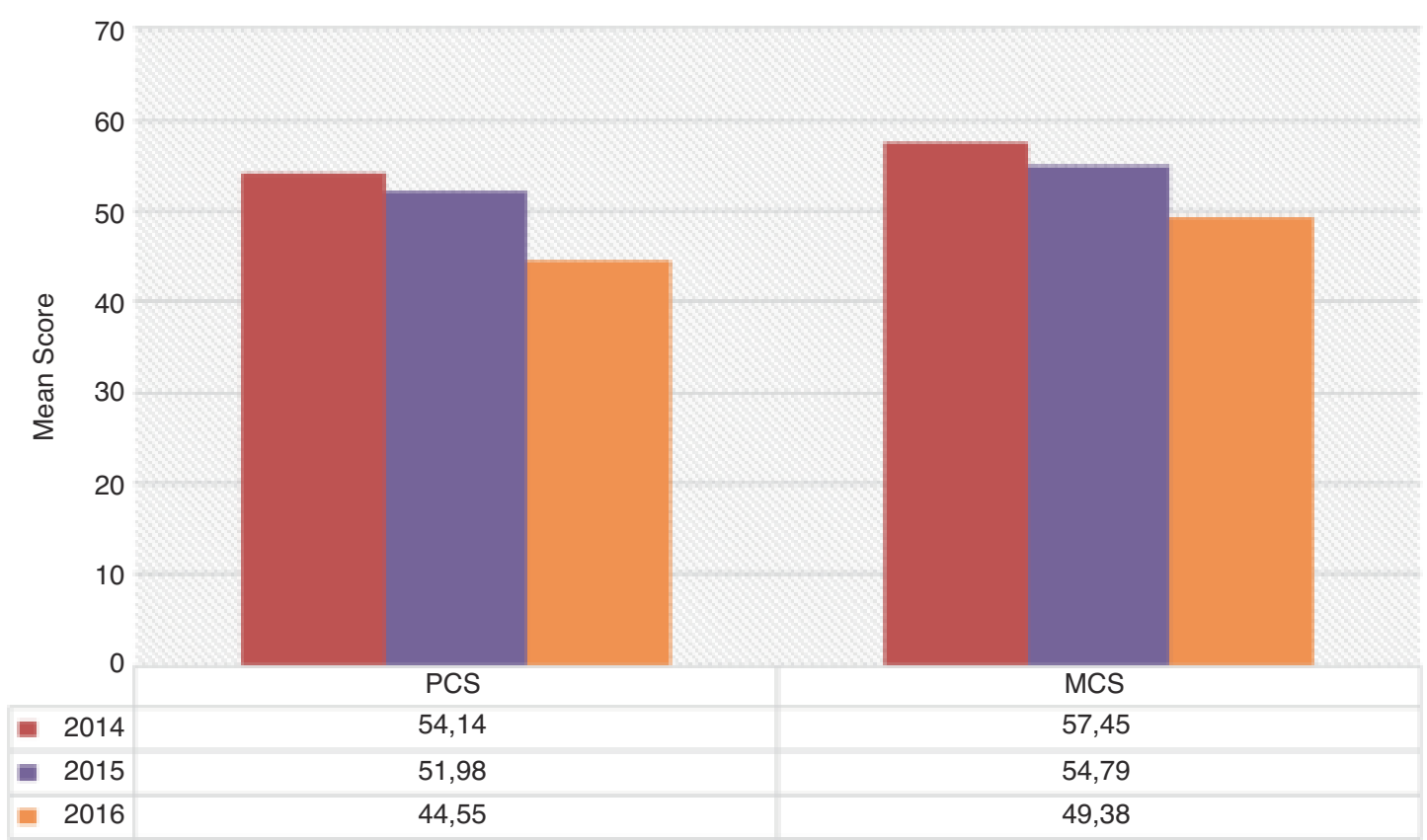

Figure 5. Mean PCS and MCS score by year of surgery in patients having TB arthropathy USTH $(n=15)$

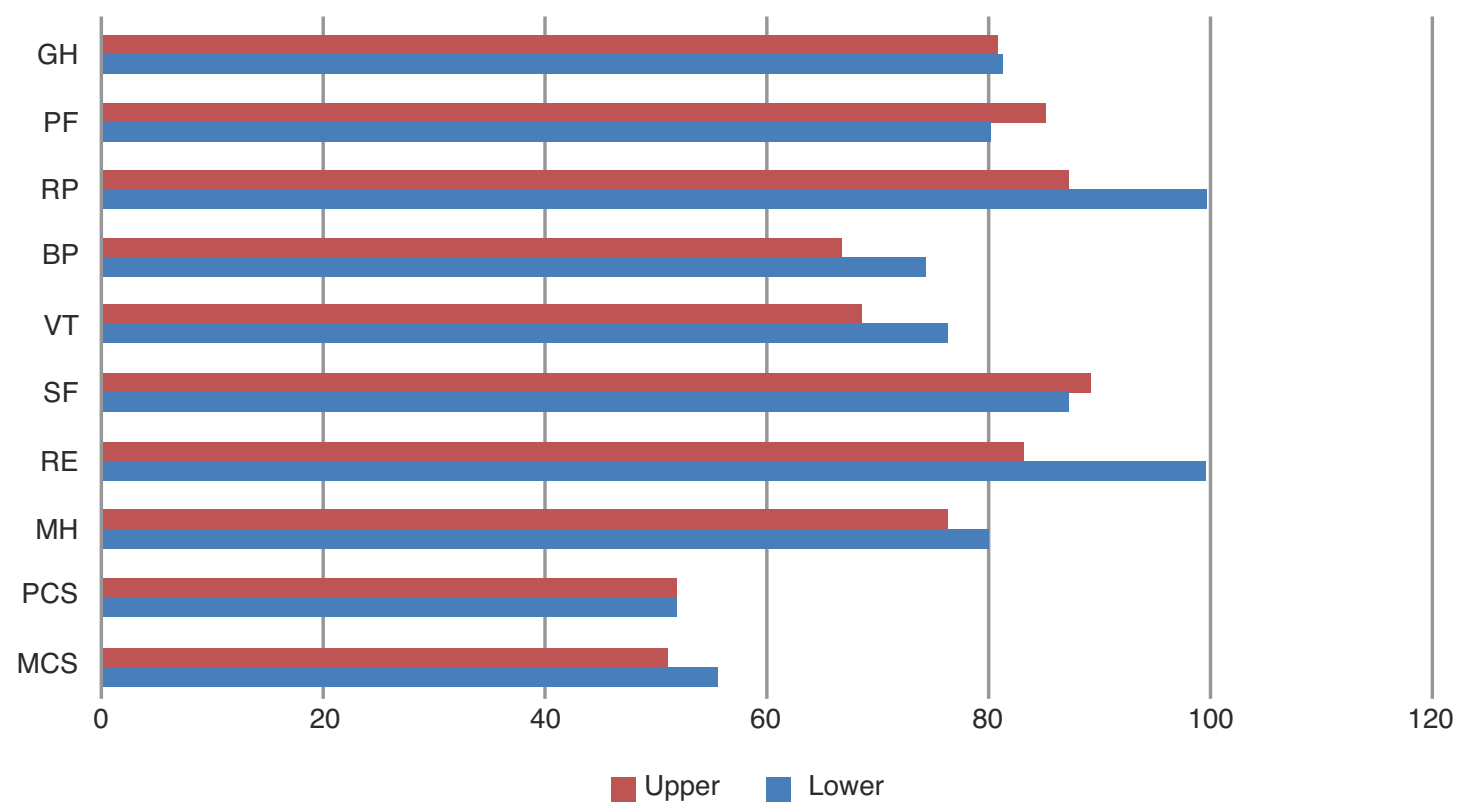

Figure 6. Mean SF-36 scores by year of extremity affected of patients having TB arthropathy in USTH $\left(n=14^{*}\right)$ * 1 patient affected in both upper/lower extremity was excluded in the analysis 
ed (all p's>0.05). GH: $p=0.9526, P F: p=0.4426$, $R P: p=0.2643, B P: p=0.4414, V T: p=0.3112$, SF: $p=0.8096, R E: p=0.2643, M H: p=0.4857, P C S:$ $p=0.9984$, MCS: $p=0.2344$. The mean scores of patients affected in the upper extremity were found to be lower except for PF and SF. In addition, the mean PCS scores were found to be comparable between the two groups.

\section{DISCUSSION}

Musculoskeletal manifestations are seen in $1 \%-3 \%$ of patients with tuberculosis. [1] In the past three years, the USTH has seen a few number of cases managed both surgically and medically.

The diagnosis of TB arthritis is delayed due to lack of awareness, insidious onset, lack of characteristic early radiographic findings and often lack of constitutional or pulmonary involvement. In the series of cases presented, most of the patients presented in our institution are in the late stages of disease that lead to some form of disability. Early-stage arthritis is considered to be the stage of synovitis and arthritis. This is characterized as periarticular demineralization, joint space widening due to effusion and mild subchondral erosion. Late-stage arthritis is considered as the stage of erosion and destruction. This is characterized as joint space narrowing, severe subchondral destruction and in some pathological subluxation and dislocation.[8] Tubercular arthritis is characteristically monoarticular and most commonly affects the spine and weight-bearing joints such as the knee, hip and ankle.[9] In our study, 14 out of 15 cases are presented as mono-articular type. Most of the pathologies were located at major weight-bearing areas such as the knee (6) and ankle joints (2).

The diagnosis of tuberculous arthritis is difficult because it can mimic an early mono-articular chronic inflammatory rheumatism, other granulomatous synovitis and pigmented villonodular synovitis.

All our cases had a bacteriological or histological confirmation after the diagnosis was suspected on the basis of chronic and destructive soft tissue or osteoarticular lesions. The diagnosis of TB arthritis is as challenging as the treatment. Still, the mainstay treatment remains anti-tuberculosis chemotherapy. [10]

Surgical procedures should be restricted to joints with severe cartilage destruction, joint deformity, large abscesses, multiple drug resistance or atypi- cal mycobacteria.[11] Our operative indications depended on both clinical and radiological features. The study of Orillaza and Tacata showed that surgery can be done as a prognosticator and for preventive measures to improve function and further complications.[9] Hence, surgical management can be both diagnostic and therapeutic at the same time.

The series of surgically treated patients mostly presented in the late stages of the disease. In spite of this, the QoL is considered to be relatively high, especially for role emotional (mean: 93.33) and the lowest mean score was obtained for the bodily pain scale (mean: 69.2). The mean score in bodily pain is significantly higher in patients who underwent surgery in 2014 compared to 2016. Higher QoL in terms of pain can be observed in patients who underwent surgery 3 years ago compared to 1 year ago. The pain subscale was also higher compared to patients who underwent surgery 2 years ago but was not statistically significant. This can be attributed since patients usually present in the later stages of the disease and have already developed some form of damage to the bone, joint and soft tissues. Furthermore, the mean score in mental health is significantly higher in patients who underwent surgery in 2014 compared to 2016. There was higher QoL in terms of mental health that can be observed in patients who underwent surgery 3 years ago compared to a year ago. The mental health subscale was also higher compared to patients who underwent surgery 2 years ago, but not statistically significant. Mentally, the treatment of TB arthropathy can also be challenging. A longer course of medical treatment is warranted in these patients and compliance commonly is a problem. Recovery from the disability caused by bone, joint and soft tissue damage can also affect the Qol of these patients.

Looking into the details of items in the questionnaire allowed us a better evaluation in which aspects patients with TB arthritis were more affected. These may guide us in counseling patients on the functional aspects that are more likely to be impaired on their way to recovery even after the duration of treatment. On the other hand, patients treated surgically and medically have good QoL outcome scores. Moreover, it can be observed in our data that the highest mean score is exhibited by patients who underwent surgery in 2014 and lowest in patients who underwent surgery in 2016. This can be attributed to the longer time of recuperation. 


\section{CONCLUSION}

All patients have good QoL scores after surgery and complete medical treatment as demonstrated by the SF-36 scores. TB arthritis can affect the physical and mental aspects of patients. No significant difference in mean scores by year were seen in all the scales of the SF-36. Although it can be observed that the highest mean score is exhibited by patients who underwent surgery in 2014 and the lowest in patients who underwent surgery in 2016 , that can be attributed to the longer period of recuperation. Patients can return to their functional capacity but can have some residual physical impairment.

\section{LIMITATIONS AND RECOMMENDATIONS}

There are several limitations to this study. First, only a single-center review was done. Another limitation is the small number of patients. Due to the limited number of cases, only a few patients were selected to be included in the study. The present study also compared different sets of patients depending on the year of surgery. They suggest that future studies do a prospective cohort study or a multicenter study to collect more patients and increase the sample size to allow more in-depth analysis like for example factors affecting QoL. 


\section{REFERENCES}

1. World Health Organization. Drug-resistant TB: surveillance and response: supplement to global tuberculosis report 2014. World Health Organization; 2014.

2. Vanhoenacker FM, Sanghvi DA, De Backer Al. Imaging features of extra-axial musculoskeletal tuberculosis. The Indian Journal of Radiology \& Imaging. 2009 Aug;19(3):176.

3. Azar FM, Canale ST, Beaty JH. Campbell's Operative Orthopaedics. Elsevier Health Sciences; 2017.

4. Ciobanu LD, Pešut DP. Tuberculous synovitis of the knee in a 65-year-old man. Vojnosanitetski pregled. 2009;66(12): 1019-22.

5. Arthanari S, Yusuf S, Nisar M. Tuberculosis of the knee complicating seronegative arthritis. The Journal of Rheumatology. 2008 Jun 1;35(6):1227-8.

6. Meena S, Gangary SK. Knee tuberculosis masquerading as pigmented villonodular synovitis. Journal of Research in Medical Sciences: the official journal of Isfahan University of Medical Sciences. 2014 Dec;19(12):1 193.

7. Mah EL, Bux SI. Tuberculous synovitis of the knee with unusually thick synovial granulation tissue: A case report. The Internet Journal of Orthopedic Surgery. 2007;2:1531-2968.

8. Gaillard F. Tuberculosis: Radiology Reference Article [Internet]. Radiopaedia. [cited 2020 Jan 15]. Available from: https://radiopaedia.org/articles/tuberculosis

9. Tacata IS. Functional outcome after treatment of TB of upper limbs. In: BMC Proceedings. BioMed Central. 2015 Dec (Vol. 9, No. 3, p. A100).

10. Kiritsi O, Tsitas K, Grollios G. A case of idiopathic bursal synovial chondromatosis resembling rheumatoid arthritis. Hippokratia. 2009 Jan; 13(1):61.
11. Betts RF, Penn RL, Chapman SW, editors. Reese and Betts' A Practical Approach to Infectious Diseases. Lippincott Williams \& Wilkins; 2003.

12. Banskota AK, Singh GK, Spiegel DA. Tuberculosis of the musculoskeletal system. Techniques in Orthopaedics. 2005;20(2): 167-78.

13. Albuquerque-Jonathan G. Atypical tuberculosis of the knee joint. South African Journal of Radiology. 2006;10(4):28.

14. Babhulkar S, Pande S. Tuberculosis of the hip. Clinical Orthopaedics and Related Research. 2002;398:93-9.

15. Laucis N, Hays R, Bhattacharyya T. Scoring the SF-36 in Orthopaedics: A Brief Guide. The Journal of Bone and Joint Surgery-American Volume. 2015;97(19): 1628-34.

Open Access This article is licensed under a Creative Commons Attribution 4.0 International License, which permits use, sharing, adaptation, distribution and reproduction in any medium or format, as long as you give appropriate credit to the original author(s) and the source, provide a link to the Creative Commons license, and indicate if changes were made. The images or other third party material in this article are included in the article's Creative Commons license, unless indicated otherwise in a credit line to the material. If material is not included in the article's Creative Commons license and your intended use is not permitted by statutory regulation or exceeds the permitted use, you will need to obtain permission directly from the copyright holder. To view a copy of this license, visit http://creativecommons.org/licenses/ by/4.0/. 


\section{APPENDIX}

Tagalog SF - 36 Questionnaire

SF-36v2
Run-in Day 1

\section{ANG IYONG KALUSUGAN AT KAGALINGAN}

Petsa kung kalian nakumpleto ang palatanungan:

$\frac{1}{\text { Araw }}+\frac{1}{\text { Buwan }}-\frac{\mathbf{2}, \mathbf{0}, \downarrow}{\text { Taon }}$

Ang kuwestiyonayong ito ay nagtatanong ukol sa lyong mga pananaw tungkol sa iyong kalusugan. Ang impormasyong ito ay tutulong na i-rekord ang iyong nararamdaman at kung gaano kagaling mo nagagawa ang iyong mga regular na aktibidad. Salamat sa pagkumpleto sa kuwestiyonaryong ito!

Sa bawat isa sa mga sumusunod na tanong, markahan ng $区$ ang isang kahon na pinaka-naglalarawan ng iyong sagot.

1. Sa kabuuan, masasabi mo bang ang kalusugan mo ay:

\begin{tabular}{|ccccc|}
\hline $\begin{array}{c}\text { Lubhang } \\
\text { napakabuti }\end{array}$ & Napakabuti & Mabuti & $\begin{array}{c}\text { Hindi masyadong } \\
\text { mabuti }\end{array}$ & Masama \\
$\square 1$ & $\square_{2}$ & $\square_{3}$ & $\square_{4}$ & $\square 5$
\end{tabular}

2. Kumpara nung nakalipas na isang taon, ano ang masasabi mo tungkol sa iyong kalusugan sa kabuuan ngayon?

\begin{tabular}{|ccccc|}
\hline $\begin{array}{c}\text { Lubhang mas } \\
\text { mabuti ngayon } \\
\text { kumpara nung } \\
\text { nakalipas na } \\
\text { isang taon }\end{array}$ & $\begin{array}{c}\text { Medyo mas } \\
\text { mabuti ngayon } \\
\text { kumpara nung } \\
\text { makalipas na } \\
\text { isang taon }\end{array}$ & $\begin{array}{c}\text { Halos parcho } \\
\text { lamang kumpara } \\
\text { nung nakalipas } \\
\text { na } \\
\text { isang taon }\end{array}$ & $\begin{array}{c}\text { Medyo mas } \\
\text { masama ngayon } \\
\text { kumpara nung } \\
\text { nakalipas na } \\
\text { isang taon }\end{array}$ & $\begin{array}{c}\text { Lubhang mas } \\
\text { masama ngayon } \\
\text { kumpara nung } \\
\text { nakalipas na } \\
\text { isang taon }\end{array}$ \\
$\square$ 1 & $\square 2$ & $\square 3$ & $\square$ &
\end{tabular}

SF-36v2 TM Health Survey ( 2003 Health Assessment Lab, Medical Outcomes Trust and QualityMetric Incorporated. All rights reserved.

SF-26 $\circledast$ is a registered trademark of Medical Outcomes Trust.

(IQOLA SF-36v2 Standard, Philippines (Tagalog)) 


\section{SF-36v2 \\ Run-in Day 1}

3. Ang mga sumusunod na katanungan ay tungkol sa mga aktibidad na maaari mong gawin sa karaniwang araw. Nalilimitahan ka ba ng kasalukuyang kalagayan ng iyong kalusugan sa mga aktibidad na ito? Kung oo, gaano?

\begin{tabular}{|c|c|c|}
\hline $\begin{array}{c}\text { Oo, } \\
\text { lubhang } \\
\text { nalilimitahan }\end{array}$ & $\begin{array}{c}\text { Oo, } \\
\text { medyo } \\
\text { nalilimitahan }\end{array}$ & $\begin{array}{l}\text { Hindi, hindi } \\
\text { nalilimitahan } \\
\text { kahit kaunti }\end{array}$ \\
\hline
\end{tabular}

a. Nakakapagod na mga aktibidad, tulad ng pagtakbo, pagbuhat ng mga mabibigat na bagay, pagsali sa mga nakakapagod na laro
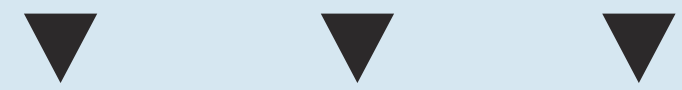

b. Katamtamang mga aktibidad, tulad

ng paggalaw ng mesa, pagwawalis,

pag-bowling, o katamtamang pagbibise-

kleta

$\square 1$

$\square^{2}$

$\square 3$

c. Pagbuhat o pagdala ng mga pinamili

$\square$

$\square 2$

$\square 3$

d. Pag-akyat sa ilang hagdanan

$\square 1$

$\square 2$

$\square 3$

e. Pag-akyat sa isang hagdanan

$\square 1$

$\square 2$

$\square 3$

f. Pagbaluktot, pagluhod, o pagyuko.

$\square 1$

$\square 2$

$\square 3$

g. Paglakad ng mahigit isan kilometro

$\square 1$

$\square 2$

$\square 3$

h. Paglakad ng ilang daang metro

$\square 1$

$\square 2$

$\square 3$

i. Paglakad ng isang daang metro.

$\square 1$<smiles>C1CCCC1</smiles>

$\square 3$

j. Pagpaligo o pagbihis sa iyong sarili

$\square 1$<smiles>C1CCC1</smiles>

SF-36v2 TM Health Survey ( 2003 Health Assessment Lab, Medical Outcomes Trust and QualityMetric Incorporated. All rights reserved. SF-26 $\otimes$ is a registered trademark of Medical Outcomes Trust.

(IQOLA SF-36v2 Standard, Philippines (Tagalog)) 


\section{SF-36v2}

Run-in Day 1

4. Sa nakaraang 4 na lingo, gaano kadalas na nagkaroon ka $\mathrm{ng}$ alin man sa mga sumusunod na problema sa iyong gawain o iba pang regular na pang araw-araw na aktibidad sanhi ng iyong pisikal na kalusugan?

\begin{tabular}{ccccc}
$\begin{array}{c}\text { Lahat ng } \\
\text { oras }\end{array}$ & $\begin{array}{c}\text { Karamihan } \\
\mathrm{ng} \text { oras }\end{array}$ & $\begin{array}{c}\text { Minsan- } \\
\text { minsan }\end{array}$ & Bihira & $\begin{array}{c}\text { Hindi } \\
\text { kahit } \\
\text { minsan }\end{array}$ \\
\hline
\end{tabular}

a. Bawasang ang daming oras na ginamit sa trabaho o iba pang mga aktibidad

$\square 1 \quad \square_{2}$

$\square^{3} \ldots \ldots . . \square^{4} \ldots \ldots . . \square 5$

b. Nakatapos ng mas kaunti sa iyong ninanais .... $\square 1$....... $\square^{2} \ldots \ldots \ldots . \square^{3} \ldots \ldots \ldots \square^{4} \ldots \ldots . . \square_{5}$

c. Nalimitahan sa uri ng gawain

o iba pang mga aktibidad

$\square 1 \ldots$

$\square 2$

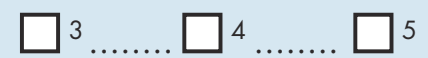

d. Nahirapan sa peggawang trabaho

- iba pang mga aktibidad (halimbawa,

nangailangan ito ng dagdag na pagsisikap) .... $\square 1$....... $\square{ }^{2} \ldots \ldots \ldots . \square^{3} \ldots \ldots . \square^{4} \ldots \ldots . . \square_{5}$

5. Sa nakaraang 4 na lingo, gaano kadalas na nagkaroon ka ng alin man sa mga sumusunod na problema sa iyong gawain o iba pang regular na pang araw-araw na mga aktibidad sanhi ng ano mang emosyonal na mga problema (gaya ng katamlayan o pagkabalisa)?

\begin{tabular}{|ccccc|}
\hline $\begin{array}{c}\text { Lahat ng } \\
\text { oras }\end{array}$ & $\begin{array}{c}\text { Karamihan } \\
\text { ng oras }\end{array}$ & $\begin{array}{c}\text { Minsan- } \\
\text { minsan }\end{array}$ & Bihira & $\begin{array}{c}\text { Hindi } \\
\text { kahit } \\
\text { minsan }\end{array}$ \\
\hline
\end{tabular}

a. Bawasang ang dami ng oras na ginamit sa trabaho o iba pang mga aktibidad

口.

$\square 1 \ldots \ldots$.

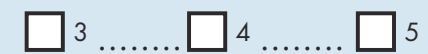

b. Nakatapos ng mas kaunti sa iyong ninanais

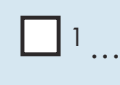

$\square^{2}$
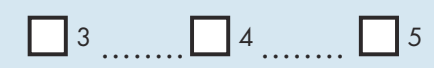

c. Ginawa ang gawain iba pang mga

aktibidad na kakaunti ang pag-iingat

gaya ng karaniwan

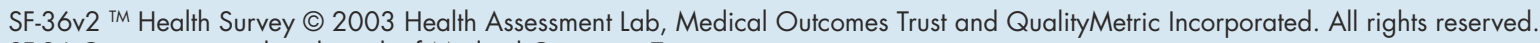




\section{SF-36v2 \\ Run-in Day 1}

6. Sa nakaraang 4 na linggo, gaano nakasagabal ang iyong mga problemang pisikal o emosyonal sa iyong mga normal na panlipunang aktibidad kasama ng iyong pamilya, mga kaibigan, mga kapitbahay, o mga grupo?

\begin{tabular}{|lcccc|}
\hline Hindi kahit kaunti & Medyo & Katamtaman & Malaki & Sukdulan \\
$\square_{1}$ & $\square_{2}$ & $\square_{3}$ & $\square_{4}$ & $\square_{5}$
\end{tabular}

7. Gaano ang naging pananakit ng iyong katawan sa nakaraang 4 na linggo?

\begin{tabular}{|lccccc|}
\hline Wala & $\begin{array}{c}\text { Kaunting- } \\
\text { kaunti }\end{array}$ & Kaunti & Katamtaman & Matindi & Napakatindi \\
$\square_{1}$ & $\square_{2}$ & $\square_{3}$ & $\square_{4}$ & $\square_{5}$ & $\square 6$
\end{tabular}

8. Sa nakaraang 4 na linggo, gaano nakasagabal ang pananakit sa iyong normal na gawain (kabilang ang gawain sa labas ng bahay at gawaing bahay)?

\begin{tabular}{|lcccc|}
\hline Hindi kahit kaunti & Medyo & Katamtaman & Malaki & Sukdulan \\
$\square_{1}$ & $\square_{2}$ & $\square_{3}$ & $\square_{4}$ & $\square$ (
\end{tabular}

SF-36v2 TM Health Survey $\odot 2003$ Health Assessment Lab, Medical Outcomes Trust and QualityMetric Incorporated. All rights reserved. SF-26 $\circledast$ is a registered trademark of Medical Outcomes Trust.

(IQOLA SF-36v2 Standard, Philippines (Tagalog)) 


\section{SF-36v2 \\ Run-in Day 1}

9. Ang mga tanong na ito ay tungkol sa kung ano ang iyong pakiramdam at ano ang iyong naging kalagayan sa nakaraang 4 na linggo. Sa bawat tanong, ibigay ang isang sagot na pinaka-akma sa iyong nararamdaman. Gaano kadalas sa nakaraang 4 na linggo...

\begin{tabular}{ccccc|}
$\begin{array}{c}\text { Lahat ng } \\
\text { oras }\end{array}$ & $\begin{array}{c}\text { Karamihan } \\
\text { ng oras }\end{array}$ & $\begin{array}{c}\text { Minsan- } \\
\text { minsan }\end{array}$ & Bihira & $\begin{array}{c}\text { Hindi kahit } \\
\text { minsan }\end{array}$ \\
\hline & & &
\end{tabular}

a. Naramdaman mo bang punung-puno ka ng buhay?

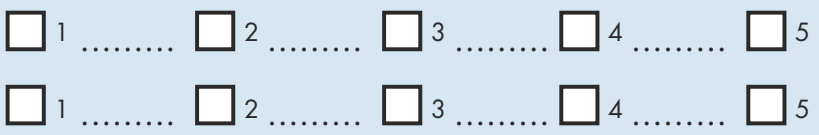

b. Ikaw ba ay naging napaka- neribiyoso?

c. Nakaramdam ka ba na sukdulan ang iyong katamlayan na walang makapagpasaya sa iyo?<smiles>C1C[Tl]1</smiles><smiles>[GeH3]</smiles><smiles>[CH]1CCCC1</smiles><smiles>[GeH3]</smiles><smiles>C1CCCC1</smiles>

d. Nakaramdam ka ba na ikaw ay kalmado at mapayapa?<smiles>[AlH2]</smiles><smiles>C1CCCC1</smiles><smiles>[C]1CCC1</smiles><smiles>[GeH3]</smiles><smiles>[GeH3]</smiles>

e. Nagkaroon ka ba ng maraming lakas na pisikal at mental?<smiles>OCC1CCCCC1</smiles>

f. Nakaramdam ka ba na ikaw ay nasiraan ng loob at matamlay?

g. Naramdaman mo bang ikaw ay naubusan ng lakas?

h. Naging masaya ka ba?

i. Naramdaman mo bang padog ka?

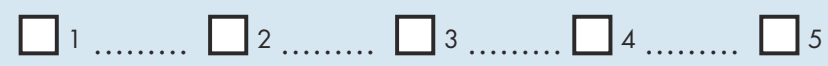

10. Sa nakaraang 4 na linggo, gaano kadalas nakasagabal ang iyong pisikal na kalusugan o mga problemang emosyonal sa iyong mga panlipunang aktibidad (gaya ng pagbisita sa mga kaibigan, kamag-anak, atbp.)?

\begin{tabular}{ccccc}
\hline $\begin{array}{c}\text { Lahat } \\
\text { ng oras }\end{array}$ & $\begin{array}{c}\text { Karamihan } \\
\text { ng oras }\end{array}$ & Minsan-minsan & Bihira & $\begin{array}{c}\text { Hindi kah } \\
\text { minsan }\end{array}$ \\
$\square 1$ & $\square 2$ & $\square_{3}$ & $\square 4$ & $\square 5$
\end{tabular}

SF-36v2 TM Health Survey $\odot 2003$ Health Assessment Lab, Medical Outcomes Trust and QualityMetric Incorporated. All rights reserved.

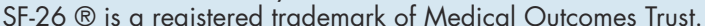

(IQOLA SF-36v2 Standard, Philippines (Tagalog)) 


\section{SF-36v2 \\ Run-in Day 1}

11. Gaano KA-TOTOO o HINDI TOTOO ang bawat isa sa mga sumusunod napahayag para sa iyo?

a. Parang medyo mas madali akong magkasakit kumpara sa ibang tao

$\begin{array}{|ccccc|}\begin{array}{c}\text { Tiyak na } \\ \text { totoo }\end{array} & \begin{array}{c}\text { Karamihan } \\ \text { ay totoo }\end{array} & \begin{array}{c}\text { Hindi } \\ \text { alam }\end{array} & \begin{array}{c}\text { Karamihan } \\ \text { ay hindi } \\ \text { totoo }\end{array} & \begin{array}{c}\text { Tiyak na } \\ \text { hindi totoo }\end{array}\end{array}$

b. Ako ay kasing lusog ng sinumang taong kilala ko
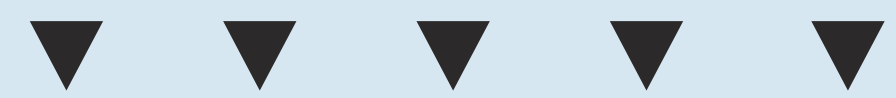

Inaasahan ko na ang aking

kalusugan ay lalala

$\square 1$

$\square 2$

$\square 3$

$\square 4$

$\square 5$

d. Ang aking kalusugan ay

lubhang napakabuti

$\square 1$

$\square_{2}$

$\square_{3}$

$\square 4$

$\square 5$

$\square 1$

$\square 2$

$\square 3$

$\square 4$

$\square 5$

........................

$1 \ldots \ldots$

$\square 2$

$\square_{3}$

$\square 4$

$\square 5$

\section{Salamat sa pagkumpleto sa mga katanungang ito!}

